Open Access

Res. Agric. Livest. Fish.

Review Article

Vol. 2, No. 2, August 2015: 185-196

\title{
POSTHARVEST BEHAVIOR AND KEEPING QUALITY OF POTTED POINSETTIA: A REVIEW
}

\section{Ashraful Islam ${ }^{1 *}$ and Daryl C. Joyce ${ }^{2}$}

1Department of Horticulture, Faculty of Agriculture, Bangladesh Agricultural University, Mymensingh 2202, Bangladesh; ${ }^{2}$ School of Agriculture and Food Sciences, Faculty of Science, University of Queensland, Gatton, Australia.

*Corresponding author: M. Ashraful Islam, E-mail: ashrafulmi@bau.edu.bd

\section{ARTICLE INFO}

\section{ABSTRACT}

Received

12.07.2015

Accepted

20.08.2015

Online

04.09.2015

Key words

Botrytis

Bract

Calcium

Ethylene

Poinsettia

Preharvest

Postharvest

Quality
Poinsettia is one of the most important potted plants in the ornamentals industry. The most attractive parts of the poinsettia are its bracts and cyathia. Stem breakage, bract fading, bract edge burn (BEB), bract bruising and bract discoloration reduce its ornamental value. The ornamental value of poinsettia is affected by both pre- and postharvest factors. During cultivation as well as after harvest, sub-optimal or improper supply and / or management of temperature, light, relative humidity, nutrition and hygiene affect the quality of potted poinsettia. A low $\mathrm{K}$ : Ca ratio can reduce the incidence of bract necrosis and stem breakage. These disorders are negatively affected by high $\mathrm{K}$ and $\mathrm{NH}_{4}-\mathrm{N}$ fertilizer due to an antagonistic relationship with $\mathrm{Ca}$. Spraying either $\mathrm{CaCl}_{2}$ or $\mathrm{Ca}\left(\mathrm{NO}_{3}\right)_{2}(400 \mathrm{mg} / \mathrm{l}$ of $\mathrm{Ca}$ per week) or a silicon spray ( $\left.7.12 \mathrm{mM} \mathrm{Na}_{2} \mathrm{SiO}_{3}\right)$ and increasing the transpiration rate by reducing the relative humidity can reduce the incidence and severity of bract necrosis. Appropriate variety selection can lessen the risks of leaf drop and BEB. Propagating with thick stemmed cuttings (> $7.5 \mathrm{~mm}$ diameter) and carefully watering of plants can also help to prevent stem breakage. The optimum temperature range to achieve expected bract color, size and bud formation during the growth period is 16 to $22^{\circ} \mathrm{C}$. Inappropriate light intensity and quality can delay flowering and promote cyathia abscission by decreasing plant carbohydrate status. Ethylene is central to the leaf and cyathia abscission. 1-MCP treatment can be used during short time (2-3 day) transportation to prevent ethylene responses by blocking ethylene receptors. Avoiding rough handling and shortening transportation play an important role in maintaining the quality of harvested poinsettia. The most important pathological problem is Botrytis infection. Low temperatures of 20 to $21^{\circ} \mathrm{C}$ during cultivation and 10 to $13^{\circ} \mathrm{C}$ during transport combined with low relative humidity of 60 to $70 \%$ RH can reduce infection by Botrytis cinera.

To cite this article: MA Islam and DC Joyce, 2015. Postharvest behavior and keeping quality of potted poinsettia: A review. Res. Agric. Livest. Fish. 2 (2): 185-196.

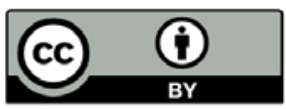

This is an open access article licensed under the terms of the Creative Commons Attribution 4.0 International License

www.agroaid-bd.org/ralf, E-mail: editor.ralf@gmail.com 


\section{INTRODUCTION}

The ornamentals or floriculture industry is a very important part of the overall horticulture industry. Cut flowers and foliage, potted flowering and foliate plants, bedding plants and nursery plants for gardens and landscapes are divisions in the floriculture industry (Chandler, 2003; Chandler and Brugliera, 2011). Poinsettia (Euphorbia pulcherrima Willd. ex Klotzsch) is one of the most important flowering potted plant lines. They are targeted to the Christmas market in regions, including in North America, Europe, Asia and Australia. This sector represents as an industry valued at over \$ 154 million per annum (Ecke et al., 2004; USDA, 2009). Poinsettia is also called 'Christmas Star'; December $12^{\text {th }}$ is designated as 'national poinsettia day' in the USA. Potted poinsettias have red, pink or white coloured bracts. Poinsettia production in the USA and the EU is 50 and $\sim 100$ million plants per year, respectively (Lütken et al., 2012). Potted poinsettia plants are exported where road transport is adequate and are moved in large numbers between countries, especially in Europe.

Poinsettia is sold for its colorful inflorescence (cyathia) and bracts (transition leaves). Important indicators of a good postharvest quality in poinsettia plants are fully formed, turgid, blemish free evenly coloured bracts and leaves along with intact, fresh-looking cyathia. The estimated postharvest loss of flowers is around 10 to $30 \%$ over all stages in the value chain (Personal communication, Sissel Torre, Norway). In the 1960's, poinsettia was sold just a week before Christmas time due to the risks of epinasty and abscission of cyathia. The epinasty problem has been largely overcome by new or modern cultivars (Personal communication, Jim Faust, USA). The most serious current postproduction disorders of poinsettia are stem breakage, bract fading, leaf yellowing, bract edge burn (BEB) or necrosis and bract bruising (Ranch, 2012; Whipker, 1999). These disorders are influenced by to varietial selection, environmental conditions and nutrition during growth and postharvest management. Ethylene plays an important role in the abscission of leaves and cyathia of poinsettia. Breeders today are focusing more on the postharvest quality of poinsettia. New cultivars with a longer postharvest life are available. Poinsettia is now-a-days in the marketplace by early November (Bævre, 1994; Odula, 2011).

As an ornamental product in an economic context, it is important to maintain poinsettia quality throughout postharvest handling and distribution from the producer to the consumer (Fig. 1). Postharvest management begins with determining the harvest maturity stage that the plants are ready for market. It continues through establishing the proper storage, transport, retail and consumer conditions. The overarching goal is to maximize crop performance and quality. Considerable research effort has been devoted to improving the keeping quality of poinsettia plants.

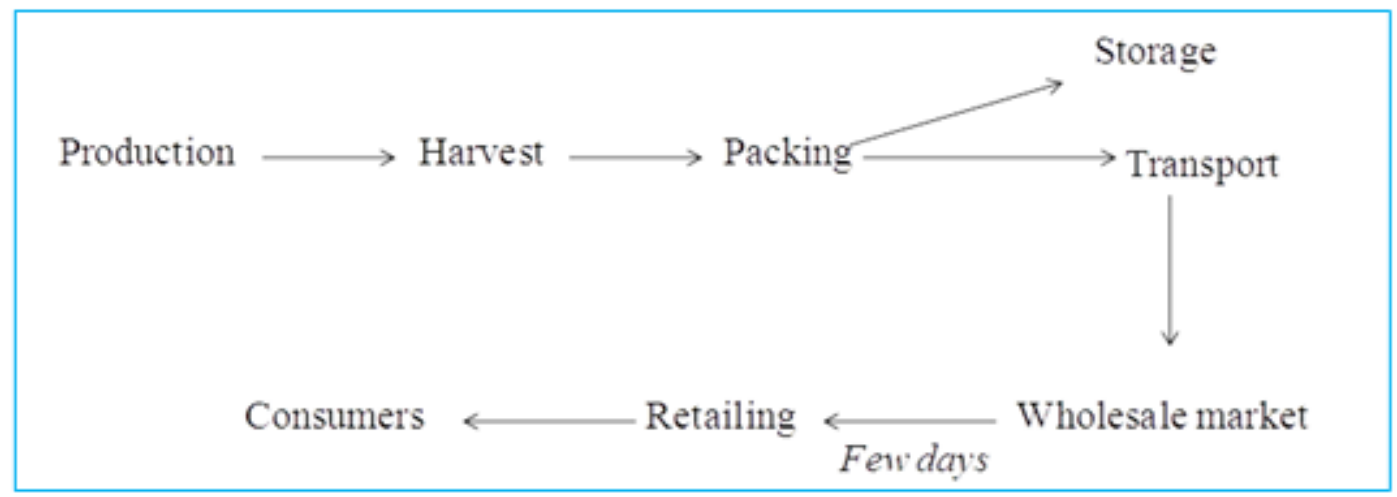

Figure 1: Flow diagram showing the serial steps of postharvest handling of ornamental plants such as poinsettia, orchid and others.

As noted above, considerable research has been carried out on poinsettia. For example, Islam et al. (Islam et al., 2012; 2013; 2014) recently worked on controlling poinsettia shoot elongation investigating light quality, hormonal physiology, genetic engineering and postharvest quality. However, there is no recent review on the postharvest quality of poinsettia. In this regard, recent research on keeping quality and postharvest behavior of poinsettia is overviewed herein. This review considers genetics, climatic factors, production techniques, nutritional disorders, transport and storage. 


\section{POSTHARVEST PROBLEMS OF POINSETTIA}

\section{Stem breakage}

Plant pinching promotes the growth of lateral shoots resulting compact plants. However, fewer shoots may develop in a horizontal orientation leading to pressure at the branch junction resulting in stem breakage (Kuehny et al., 2000). Low light levels during the vegetative growth phase after pinching can contribute to poor structural development in the crotch area and / or lateral weak branch growth (Fig. 2A). Small diameter cuttings, improper plant spacing and inappropriate fertilization can also influence lateral stem breakage. Stem breakage is problematic during production and / or after sleeving. Such breakage markedly reduces market value and, thus, economic returns.
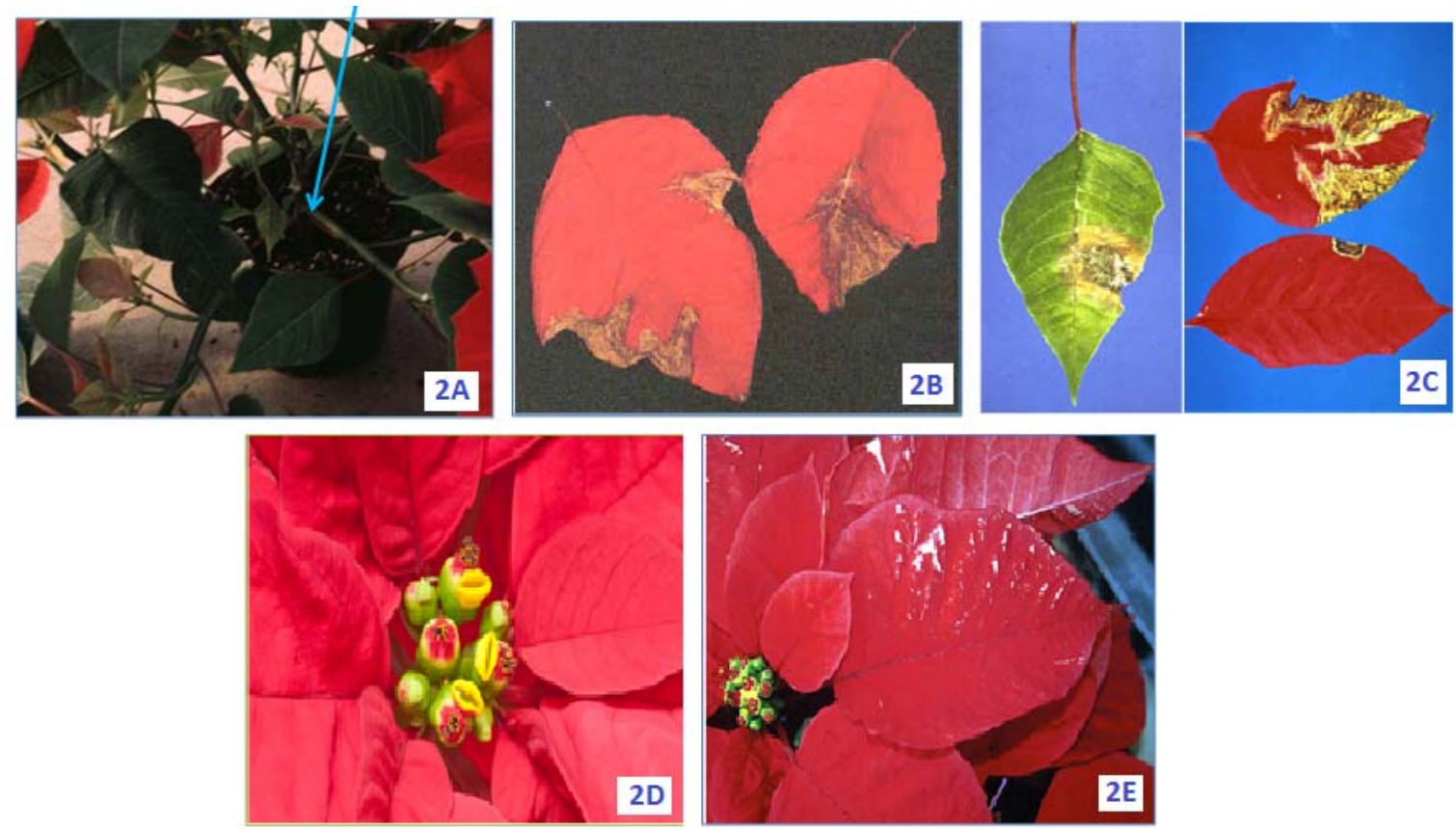

Figure 2A: Weak lateral stems (arrows) that tend to stem breakage (Hammer, 1999)

Figure 2B: Bract necrosis/bract edge burn (BEB) (Tayma and Roll, 1990)

Figure 2C: Botrytis infected leaf (left) and bracts (right) (Jones, 1999)

Figure 2D: Bracts (transition leaves) and cyathia of poinsettia (Photo: Md. Ashraful Islam)

Figure 2E: Bract abrasion (arrow) due to excessive contact (Whipker, 1999)

\section{Bract necrosis and Botrytis infection}

Bract necrosis is also called bract edge burn (BEB) (Fig. 2B). BEB starts as small brown necrotic lesions along the bract margin. The lesions may expand through the develop Botrytis infection to damage the entire bract that essentially renders the plants unmarketable. Low level of calcium might be the reasons of the disorder or bract margin. On the other hand, calcium translocating system is difficult in some varieties which are essential elements for the cell expansion. It will not be possible to solve using more application of calcium which are cultivar dependant (Ranch, 2011). Botrytis blight or gray mold (Fig. 2C) is caused by the fungal pathogen Botrytis cinerea. In poinsettia, Botrytis blight can occur at all stages during production and postharvest. Regardless of the tissue affected, the rot begins as water soaking developing into tan to brown lesions.

Excess fertilizer application, particularly ammonium sources of nitrogen at the late stage production, can lead to bract burn and then $B$. cinerea infection. It is considered that contributory factors to bract necrosis include excess soluble salt levels in the growing medium that causes root injury, reduced water absorption stress from excessive or insufficient irrigation, damage from pesticides, pollutants, and high relative humidity.

\section{Leaf drop and yellowing}

A lack of irrigation water can cause leaf drop that affects older leaves. Leaf fall under stress conditions occurs at an abscission layer at the junction of petiole and the stem. It is believed that leaf drop is mediated by a loss of auxin export across the abscission zone from the leaf blade under stress condition. Irregular 
irrigation, low light intensity, warm temperature and low relative humidity are thought to influence leaf drop at any level in the supply chain up to and including where the poinsettia place is placed by the consumer. In particular, the lower leaves yellow and drop if the plants are kept under very low light intensity for several days.

\section{Cyathia abscission}

Premature abscission of one or more of the cyathia or true flowers on poinsettia also reduces the ornamental value (Fig. 2D). Abscission per se results from degradation pectin in the mid-lamella and of pectin, cellulose and arabinose in cell walls of the abscission zone (AZ). The levels of xylan and xyloglucan in the AZ zone is shown to increase prior to abscission, rendering the cell walls more loosely organized and susceptible to degradation (Lee et al., 2008).

\section{Bract discoloration I abrasion}

Poinsettia bracts are fragile and easily discolor. They can be severely damaged by temperatures below $10^{\circ} \mathrm{C}$ (Love, 1999). Expansion of discoloration depends on the duration of exposure to such cold temperature. Red bracts develop a blue to silver white color (Fig. 2E). During shipping, bract abrasion occurs due to rubbing against the sleeve or against each other. Sleeves and boxes which are taller than the plants can help to prevent bract abrasion as well as confer a degree of protection against chilling injury.

\section{IMPROVING THE POSTHARVEST QUALITY OF POINSETTIA}

\section{Genotype}

Genotype or cultivar selection is one of the most critical decisions for growers. Poinsettia breeding has attracted considerable attention resulting in increased demand for better quality cultivars. Thus, cultivar selection is important to the commercial grower. New poinsettia cultivars are introduced by poinsettia breeding companies each year. A national poinsettia trial programme has been evaluating poinsettia cultivars with the collaboration of poinsettia breeding companies for over 19 years since started in 1993. Barrett and Dole (2012) surveyed 21 new poinsettia cultivars of varying color and type in three locations in a comparison with established cultivars. Cultivar 'Ice Punch' was selected as the best cultivar with strong (46\%) consumers support. Dunn et al. (2011) studied 40 cultivars at different temperatures and determined differences in bract numbers, size and lateral shoots among the cultivars. BEB emerged as a major problem in the late 1970s with the introduction of 'Gutiber V-14 Glory'. Now-a-days it is considered that BEB is cultivar dependent (Ranch, 2011).

Self-branching cultivars, such as 'Annette Hegg Dark Red' and 'Gutibar' havethin stems that are prone to bend and break during handling or shipping (Larson et al., 1978). Some cultivars like 'Success' and 'Red Splendor' are relatively more resistant to stem breakage (Whipker, 1999). More recently introduced cultivars show better postproduction quality as compared to older ones. Some newer varieties were evaluated by Ranch (2012) for their relative postproduction problems. All varieties are ranked into the categories of 'excellent', 'good' or 'below average' after 4 weeks considering postproduction performances like bract edge burn (BEB), bract fading, leaf yellowing, leaf drop, bract bruising etc.

\section{Environmental factors}

\section{Light}

Light intensity during the growth period can affect the post-production keeping quality of potted ornamental plants (Fjeld, 1990). In poinsettia, low light intensity was shown to reduce stem strength, delay flowering and increase cyathia abscission (Faust et al., 1998; Fjeld, 1992; Moe et al., 1992a; 2006). A stem breakage problem was observed by Kuehny et al. (2000) in cv. 'Freedom Red'. Due to pinching, a large number of lower laterals grew out and upwards towards light. This growth habit caused weaker lateral stems and wider lateral branch angles, especially in lower stems. In general, after pinching the competition for light during the vegetative growth causes weak lateral branching (Smith and Cox, 2009).

An increase in irradiation from 12 to $73 \mu \mathrm{mol} . \mathrm{m}^{-2} . \mathrm{s}^{-1}$ during production increased cyathia retention in the $1^{\text {st }}$ and $2^{\text {nd }}$ weeks of postharvest testing under indoor climate conditions (Moe et al., 1992b). Extending the photoperiod from $10 \mathrm{~h}$ to $24 \mathrm{~h}$ the last 3 weeks of production resulted in higher postharvest cyathia abscission rate and discoloration. Moe et al. (2006) tested postharvest performance of cvs. 'Lilo' and 'Millenium' and established differences. Bract discoloration occurred on 'Lilo' under production in a $24 \mathrm{~h}$ photoperiod as compared to the $10 \mathrm{~h}$ control treatment. One hundred (100) \% bract discoloration occurred in 'Lilo' during the last 3 weeks of cultivation under the $24 \mathrm{~h}$ photoperiod. However, 'Millenium' showed no discoloration in red bract under control as well as with the supplemental light of $24 \mathrm{~h}$ photoperiod. Carbohydrate depletion might be the reason for cyathia abscission. It is not clear about the retention capacity of cyathia in different cultivars 
(Moe et al., 2006). Bract discoloration may be a result of accumulation of anthocyanin or other phenolic compounds under high light intensity or long photoperiods. Petal blackening of roses occurred due to this phenomena at low night temperature exposure (Zieslin and Halevy, 1969). Overall, premature abscission is interlinked with long photoperiod and low light intensity (Scott et al., 1983; 1984a; Staby and Kofranek, 1979).

Carbohydrate status and sugar supply to floral organs likely play a role in cyathia abscission (van Doorn, 2001). In Christmas begonia, Fjeld (1992) measured sucrose content and abscission rate during the marketing stage for plants grown at different irradiance level. The sucrose content was a higher contributor to the dry matter of inflorescences and leaves (10\%) and the abscission rate was lower for flowers and buds (19\%) on plants grown under $60 \mu \mathrm{mol} . \mathrm{m}^{-2} . \mathrm{s}^{-1}$ as compared to $15 \mu \mathrm{mol} . \mathrm{m}^{-2} . \mathrm{s}^{-1}(2.1 \%$ sucrose and $36 \%$ abscission).

Towards saving energy and manipulating plant growth in an environmentally sounder manner that also improves plant health, the use of specific light qualities provided by light emitting diodes (LED) is attracting attention. It is well known for a variety of long day plants that blue $(B)$ and red $(R)$ light promote flowering while far-red (FR) delays flowering (Simpson and Dean, 2002). No difference in the keeping qualities of poinsettia cvs. 'Christmas Spirit' and 'Christmas Eve' was found after exposure to LED lamps providing $80 \%$ R and $20 \%$ $B$ light irradiance at $100 \mu \mathrm{mol} . \mathrm{m}^{-2} \cdot \mathrm{s}^{-1}$ (Islam et al., 2012). Light quality manipulation resulting in an increased $\mathrm{R}$ : FR ratio at the EOD (end of day) for 30 min used to avoid unwanted extension growth. It is well known that both phytochrome and cryptochrome are involved in the content of hormone gibberellin (Hisamatsu et al., 2005; Zhao et al., 2007). However, this treatment did not have any effect on the flowering of the two cultivars of poinsettia (Islam et al., 2014). Nevertheless, postharvest behavior is cultivar dependent. It has been recorded that the senescence of poinsettia was faster under fluorescent lamps as compared to under incandescent tungsten lamps (Scott et al., 1984a).

\section{Temperature}

Stem breakage, flower bud formation, flower development, bract color, bract size, bract discoloration, bract necrosis and Botrytis infection are all influenced by temperature during the plant growth period. Pritchard et al. (1996) observed that the bract and foliage infected area increased during the postproduction, if the temperature is increased both at day and night time from 16 to $22^{\circ} \mathrm{C}$ during the poinsettia production. Higher temperature was considered to increase turgor pressure that resulted in the extracellular leakage of nutrients, salts and sugars in the bract and to the leaf surface which influence the germination of Botrytis cinera conidia (Blakeman, 1975; Salinas et al., 1989; Van Meeteren, 1980). As per above, common symptoms caused by Botrytis infection are leaf spots and blighting which may affect leaves, stems and petioles (Hausbeck and Moorman, 1996). Schnelle and Barrett (2011) recorded chroma values for bract fading or discoloration at $27^{\circ} \mathrm{C}$ as compared to at 21 and $24^{\circ} \mathrm{C}$. Bract discoloration at the higher temperature of $27^{\circ} \mathrm{C}$ gave a chroma value of 39 as being significantly lower than 55 at $21^{\circ} \mathrm{C}$ and 54 at $24^{\circ} \mathrm{C}$. Also, it has been observed that $\sim 34 \%$ lateral shoots were broken at a relatively lower temperature and $4 \%$ at a higher temperature while the night temperature was maintained at $20^{\circ} \mathrm{C}$ with the day temperature was 30 or $37^{\circ} \mathrm{C}$ (Faust et al., 1998). Too low average daily temperatures cause slowed plant development, delayed color development, reduced bract size and elicited lower leaf loss from poinsettia plants (Whipker, 1999). Runcle and Faust (2008) reported that poinsettias growth stopped at $<13^{\circ} \mathrm{C}$.

Moe et al. (1992a) tested the keeping quality of poinsettia plants grown under different day and night temperatures (DIF). A negative temperature difference between day and night (DT < NT) was found to delay flowering (Moe et al., 1992a; 1995). In these plants, bract necrosis and cyathia abscission were higher during the $1^{\text {st }}$ and $2^{\text {nd }}$ week postharvest as compared to plants that experienced positive (DT > NT) and zero (DT = NT) DIF. After 4 weeks, there was no difference in bract necrosis between the plants grown under the different temperature treatments. Although there is limited information on the effect of temperature on carbohydrate status in poinsettia, premature cyathia abscission is probably linked to carbohydrate depletion (Miller and Heins, 1986). Photosynthetic rates are correlated with temperature and a lower photosynthetic rate was found under negative DIF as compared to positive and zero DIFs (Berghage et al., 1990). Moe et al. (1992a) mainly applied negative DIF to get compact plants, but the postharvest quality was not good. However, such a treatment given early in poinsettia production with an ADT (average daily temperature) 23 to $26^{\circ} \mathrm{C}$ from visible bud formation to flowering can result in compact plants without serious reduction in postharvest quality (Berghage, 1989). Temperature after flowering appears to be important for the keeping quality of poinsettia. In general, the optimum temperature for bract development is 22 to $23^{\circ} \mathrm{C}$ during the day and 19 to $20^{\circ} \mathrm{C}$ at night. Before shipping for 2 weeks, the temperature should be maintained at $21^{\circ} \mathrm{C}$ and $20^{\circ} \mathrm{C}$ day and night, respectively, during production (Whipker, 1999). The lowest postharvest quality rating was scored at $\angle 17^{\circ} \mathrm{C}$ in regard of leaf yellowing, cyathia drop and bract edge burn (Syngenta (2009).

\section{Water and air humidity}

Water supply and air humidity conditions affect the morphological and physiological condition of ornamental plants, including their postharvest life. It is claimed that excess water stress or water deficiency stress both interfere with the longevity of plant organs. Despite this general understanding, the effects of water 
supply on the longevity of ornamental plants have not been comprehensively examined. Water supply and air humidity both have correlative influences on plant transpiration s. For instance, the water consumption per unit leaf area is lower at higher humidity and Mortensen (2000) mentioned that water consumption per unit area of leaf is decreased $39 \%$ in poinsettia during the water vapour pressure deficits (VPD) decreased from 660 to $155 \mathrm{~Pa}$.

The effect of air humidity on keeping quality is unclear for poinsettia and other greenhouse grown flowering plants (Grange and Hand, 1987). However, deficit irrigation and low air humidity can both stimulate tissue dehydration to cause lower stomatal conductance values (gs) reflecting efficient stomatal regulation (Sánchez-Blanco et al., 2004). Drought stress to water potentials of -1.3 to $-1.1 \mathrm{MPa}$ can elicit leaf drop in poinsettia during the reproductive growth stage (Gilbertz et al., 1982; Whipker, 1999). Drought stress may induce endogenous ethylene resulting premature loss of organs.

In contrast, high humidity can reduce the rate of transpiration (Ehret and Ho, 1986). Mortensen (2000) observed transpiration rates for poinsettia during the growth at air humidities of $70 \%, 81 \%$ and $93 \%$. The transpiration rate was higher at $31.9 \pm 2.9 \mathrm{~g}$. day ${ }^{-1}$ under $70 \% \mathrm{RH}$ as compared to $23.7 \pm 2.2 \mathrm{~g}^{\text {. day }}{ }^{-1}$ under $93 \% \mathrm{RH}$. It has been shown that Ca plays an important role for postharvest life of ornamental plants like cut roses and Antirrhinum. Ca uptake and transport are affected by transpiration rate (Higaki et al., 1980; Marschner, 1995; Michalczuk et al., 1989; Nielsen and Starkey, 1999; Starkey and Pedersen, 1997). As previously described, $\mathrm{Ca}$ is integrally related to bract necrosis and stem breakage of poinsettia. Tissues having low xylem flow due to low transpiration rate have low translocation of $\mathrm{Ca}$ into the bracts leading to bract necrosis. Thus, the $\mathrm{Ca}$ content becomes lower in bracts and leaves of poinsettia grown at high $\mathrm{RH}$ as compared to for those grown at moderate $\mathrm{RH}$. Similar results were found for flowers and leaves of cut roses grown under high $\mathrm{RH}$, resulting in their comparatively shorter postharvest life (Baas et al., 1998; Strømme et al., 1994; Torre et al., 2001). There also appears to be a difference in transpiration rates between the bracts and leaves of poinsettia. Consequently, the $\mathrm{Ca}$ content is commonly lower in the bract (Robichaux, 2008; Strømme et al., 1994). Insufficient $\mathrm{Ca}$ in bracts may be due to low stomatal density in this relatively low transpiring organ (Nell and Barrett, 1986a).

Both high air humidity and water stress favor B. cinerea in greenhouses (Hausbeck and Moorman, 1996; Whipker, 1999). During the growing phase, roots are primarily affected. Infection may later cause stem rot and plant death. Stressed or wounded leaf tissues and true flowers of poinsettia are particularly affected by $B$. cinerea. Low Ca levels favour this pathological disorder (Ranch, 2011). Lowering the air humidity, maintaining good air circulation, reducing moisture in the plant canopy, cleaning away plant debris, and application of approved fungicides like benzimidazole and dicarboximide can prevent $B$. cinerea. During production, small physical breaks sometimes occur at branch and main stem junctions under to force of hand watering. Watering gently can reduce this type of stem breakage.

\section{Management practices}

\section{Cuttings and space}

Poinsettias are vegetatively propagated by cuttings. Stem breakage, which is the most important production problem in poinsettia, is affected by cutting diameter. Two times more stem breakage was observed for $4.5 \mathrm{~mm}$ or less cutting diameters as compared to $7.5 \mathrm{~mm}$ or greater diameters (Ranch, 2011). Poinsettia plant development is weak from thin diameter cuttings. Consequently, resulting inflorescences cannot be kept erect without the staking. Plants growing in pots from cuttings should be placed close together at the beginning of production cycle in order to encourage upright growing. Otherwise, angled to horizontal lateral shoots will be produced in the open space. In addition to thicker stem cuttings, support rings can help prevent stem breakage.

\section{Nutrition}

Fertilization influences the postproduction performance of poinsettia. The greatest difference in $\mathrm{Ca}$ contents in the interior part of leaf blades was between healthy leaves and those suffering from leaf edge burn (LEB). At the end of the postharvest period, Ca content was analyzed in the bracts of poinsettia (Strømme et al., 1994). The Ca content was lower at the margin as compared to middle or interior bract sections, indicating localized Ca deficiency. McAvoy et al. (1998) observed condensed tannins in bract tissues with necrotic lesions as compared to healthy tissue.

Application of a high $\mathrm{NH}_{4}-\mathrm{N}$ fertilizer level indirectly resulted in necrotic spots by reducing $\mathrm{Ca}$ absorption (Nell and Barrett, 1985). On the other hand, high $\mathrm{NH}_{4}-\mathrm{N}$ treatment in solution ' $\mathrm{A}$ ' was associated with the lowest incidence with no influence on Ca uptake (Strømme et al., 1994). It has been reported that BEB increased by two fold when the nitrogen $(\mathrm{N})$ supply concentration was increased from $200 \mathrm{ppm}$ to $400 \mathrm{ppm}$ (Ranch, 2011). The reason may be that $\mathrm{NH}_{4}$ is converted to $\mathrm{NO}_{3}$ quickly such that very little $\mathrm{NH}_{4}$ is left to compete with $\mathrm{Ca}$ uptake. Ammonia-nitrogen promotes vegetative growth that may lead to also vegetative 
growth as well as weaker stem resulting stem breakage (Whipker, 1999). After application of different ratios of $\mathrm{NH}_{4}-\mathrm{N}: \mathrm{NO}_{3}-\mathrm{N}(0.1,1.2$ and 2.1$)$ during production, a difference was detected in Ca contents between the outer margins and the interior section of leaf blades (Biermann et al., 1990).

Although the mechanism is not entirely clear, spraying with $\mathrm{CaCl}_{2}$ and $\mathrm{Si}$ can suppress bract necrosis development, (McAvoy and Bible, 1996a; 1996b; McAvoy et al., 1998; Woltz and Harbaugh, 1985). Si spray reduces the incidence of bract necrosis / LEB without effects on macro or micro nutrient contents in the leaf / bract margin tissues (McAvoy and Bible, 1996b). Si is taken up by plant roots in the form of silicic acid and transported to the shoot. Si treatment can reduces the plant transpiration rate (Ma and Takahashi, 2002). Termination of Si fertilization 1 to 4 weeks prior to harvest appears to reduce leaf drop (Prince and Cunningham, 1988; Ranch, 2011). Ca and Si treated poinsettia plants typically show better stem strength (Kuehny et al., 2000; Robichaux, 2008). Ca plays a key role in cell wall structure. It is involved in cross-linking pectin molecules (Ferguson and Drøbak, 1988; Hepler, 2005). As above, poinsettia stem breakage, leaf edge burn (LEB) and bract necrosis are reportedly linked to calcium (Ca) supply and can be improved by spraying with Ca and silicon (Si) (McAvoy and Bible, 1995; Robichaux, 2008; Woltz and Harbaugh, 1985).

There is an apparent antagonistic relationship between potassium (K) and $\mathrm{Ca}$ (Tsutsui and Aoki, 1981). $\mathrm{Ca}$ is translocated from the root to the different parts of the shoot through the transpiration stream in the xylem and Ca mobility through the phloem is limited (Strømme et al., 1994). Substrate pH is important for poinsettia production. Leaf edge burn occurs and mature leaves in the middle of the plants become yellow due to molybdenum (Mo) deficiency (Whipker et al., 2002). At pH 6.5, new leaves become yellow due to iron (Fe) deficiency.

\section{Storage and transportation}

In addition to production factors, the keeping quality of poinsettia is dependent on postproduction factors. Deterioration occurs quickly such that the ornamental value is reduced due to poor treatment, handling, transportation and storage. It is important to understand the plants physiological requirements in respect to postharvest environmental factors (e.g. light, temperature, air humidity) from harvest to the consumer (Fig. 1). In general, growers, distributors and wholesalers use preservative chemicals, hygiene and cold chain management to maintain product quality (Eason, 2006). In poinsettia, problems such as bract discoloration, leaf yellowing, and shrinkage in terms of plant losses occur during the postharvest period. These issues mean lower returns and ultimately to cost cutting on the input side. Thus, it is vitally important to give due care and attention to proper handling, transportation, and storage to retain harvest quality.

In Norway by way of example, poinsettia plants are placed either in open framed Danish containers or into sleeves and boxed before leaving the growers premises for transportation. As poinsettia is a chilling sensitive species, the paper sleeves may protect the plants from low temperature injury. Leaf drop and bract discoloration can occur due to non-optimal temperatures and long durations of storage. These disorders are associated with ethylene and auxin physiology (Sacalis, 1978; Saltviet et al., 1979; Staby et al., 1980; 1978). Active auxin transport inhibits the formation of abscission layers by reducing abscission zone sensitivity to ethylene. On the other hand, ethylene inhibits the transport of both indole-3-acetic acid (IAA) and $\alpha$ naphthalene acetic acid (NAA) in midrib sections, resulting in reduced auxin transport through the abscission zone (Riov and Goren, 1979). Ethylene is considered the primary regulator of abscission process and auxin acts as a suppressor of the ethylene effect (Taiz and Zeiger, 2010).

Faust and Enfield (2010) suggested that 10 to $15^{\circ} \mathrm{C}$ is the optimum temperature range for shipping of unrooted poinsettia. Higher temperatures can increase ethylene concentrations. For example, ethylene increased over $48 \mathrm{~h}$ from 0.0 to $0.5 \mathrm{ppm}$ with increasing temperature from 10 to $26^{\circ} \mathrm{C}$ in plastic bags packaged un-rooted poinsettia cuttings while ethylene was measured at 12, 24, 48 and $72 \mathrm{~h}$ (Faust and Lewis, 2005). Following $72 \mathrm{~h}$ storage, 4 days in propagation, the leaf abscission was increased at the temperature from 10 to $26^{\circ} \mathrm{C}$.

Light is also known to influence auxin content and thus leaf drop. Decreased cyathia retention occurred during storage for 3 to 6 d under darkness (Scott et al., 1982,1984b; Shanks et al., 1970). In retail shops, poinsettia plants are typically packed tightly on shelves tightly in low light. Their deterioration under such conditions reduces their ornamental value.

Ethylene can stimulate abscission of whole flowers and flower buds from ornamental plants (Woltering, 1987). Among other chemical compounds, 1-methylcyclopropene (1-MCP) can effectively block ethylene responses at the receptors (Serek et al., 2006). 1-MCP has been shown to protect many potted plants as well as other horticultural produce against ethylene action (Faust and Lewis, 2005; Serek et al.,1994; Serek et al., 2006). It can be used in shipping boxes or containers. Preventing gas leakage during treatment makes for effective delivery. Faust and Lewis (2005) used 1-MCP sachets during shipment to prevent the ethylene action and reduce leaf yellowing and abscission in un-rooted poinsettia cuttings. Similar findings were found in Pothos (Epipremnum pinnatum) (Muller et al., 1997). Faust and Lewis (2005) showed a potential benefit of placing 1-MCP sachets in with un-rooted poinsettia cuttings shipped at the relatively warm temperature of 18 
to $26^{\circ} \mathrm{C}$. At low temperature $\left(5\right.$ to $\left.10^{\circ} \mathrm{C}\right), 1-\mathrm{MCP}$ is not necessarily needed due to low ethylene production at low temperature (Jiang et al., 2002).

Botrytis disease is favored at room temperature due to injured or succulent tissue (Ecke et al., 1990). Infection can occur during transportation, particulary if the plants become too wet with moisture on their foliage. Temperature fluctuations during transportation and / or storage commonly result in high humidity and condensation of water onto bracts or leaves. Thus, maintaining a stable temperature is important. The optimum temperature appears to be about 12 to $13^{\circ} \mathrm{C}$. A low temperature of $<4^{\circ} \mathrm{C}$ results in chilling injury and higher temperatures of 16 or $24^{\circ} \mathrm{C}$ are associated with leaf abscission (Nell and Barrett, 1986b; Scott et al., 1983).

In general terms, it can be difficult to manage poinsettia plants during shipping or on retail display in respect to providing proper light and water management (Barrett, 2011). Darkness is a particularly poor condition for the plant. Sleeving plants can avoid damage during handling by customers.

\section{RECOMMENDATIONS}

The keeping quality of poinsettia plants is influenced by cultivar selection, optimum pre-harvest cultural and pre- and postharvest environmental conditions (viz., temperature, light, air humidity) as well as general management practices, including during transportation and storage. To maintain high-quality poinsettia plants, the following guidelines may be followed.

- Selection of 'new' poinsettia cultivars which are less susceptible to BEB and leaf drop as compared to 'old' cultivars.

- Avoidance of high temperature after flowering and maintenance of an optimum growing temperature of 20 to $21^{\circ} \mathrm{C}$

- Provision of at least100 $\mu \mathrm{mol} \cdot \mathrm{m}^{-2} \cdot \mathrm{s}^{-1} \mathrm{~B}(20 \%)$ and R (80\%) LED light for growing poinsettia for no negative effect on postharvest behaviour. Under indoor conditions, a minimum irradiation of $10 \mu \mathrm{mol}$. $\mathrm{m}^{-2} \cdot \mathrm{s}^{-1}$ should be provided by fluorescent tubes.

- Maintenance of 60 to $70 \%$ air humidity for poinsettia production and around 40 to $60 \% \mathrm{RH}$ for postharvest and / or indoor conditions.

- Achievement of an optimum temperature range at between 10 to $13^{\circ} \mathrm{C}$ during transportation and avoidance of excess water during storage with a view to minimise BEB and Botrytis infection. Long distance transport for $>3 \mathrm{~d}$ should be avoided and 1-MCP sachets can be used.

- At retail level, realising a minimum light level $\left(10 \mu \mathrm{mol} . \mathrm{m}^{-2} . \mathrm{s}^{-1}\right)$ and a temperature of about 18 to $20^{\circ} \mathrm{C}$ in the shop. Plants should ideally be kept on shelves or racks with spacing that ensures optimum light to them all. A few plants might be separated display with the aim of avoiding rough handling of the others by consumers.

- Optimum fertilization should be practised with thought to $\mathrm{K}, \mathrm{Ca}$ and $\mathrm{N}$ due to potential antagonistic effects. EC and pH levels should be considered. Towards the end of the production phase, applications of $\mathrm{K}$ and $\mathrm{NH}_{4}-\mathrm{N}$ should be reduced. Conversely, Ca should be applied during the last weeks before harvest.

- Spraying of leaves and bracts with calcium chloride or calcium nitrate (400 mg/l of Ca per week) or with silica $\left(7.12 \mathrm{mM} \mathrm{Na}_{2} \mathrm{SiO}_{3}\right)$ to reduce the incidence and severity of necrosis. Also, maintenance of low air humidity with a view to increasing plant organ Ca contents and minimising Botrytis blight.

\section{ACKNOWLEDGEMENTS}

First author would like to give thanks to Professor J.E. Olsen, Dr Sissel Torre and Dr J.L. Clarke, Norway who encouraged to write this paper. Also, thanks to Dr Jim Faust, USA who updated on some information on poinsettia. First author is grateful to Professor Daryl C. Joyce, Australia for continuous support as well as for the critical reviewing of this manuscript. Finally, both authors are decided to dedicate this manuscript to Professor Adel A Kader who was very devoted to science especially in postharvest technology in his life.

\section{REFERENCES}

1. Baas $\mathrm{R}, \mathrm{N}$ Marissen and A Dik, 1998. Cut rose quality as affected by calcium supply and translocation. Acta Horticulturae, 518: 45-54.

2. Bævre O, T Fjeld and R Moe, 1994. Poinsettia production in the north. In the scientific basis of poinsettia production, The AgriculturalUniversity of Norway, Ås, Norway.

3. Barrett J, 2011. The effect of shipping and handling on poinsettia marketability. GPN Magazine. (http://www.gpnmag.com/effect-shipping-handling-poinsettia-marketability-0). 
4. Barrett J and J Dole, 2012. The consumers response to poinsettia cultivars. North American poinsettia trials. GPN Magazine in March.

(http://www.gpnmag.com/sites/default/files/06_Poinsettia_GPN0312\%20FINAL.pdf).

5. Berghage RD, 1989. Modeling stem elongation in the poinsettia. PhD Dissertation, Michigan State University, USA.

6. Berghage RD, JA Flore, RD Heins and JE Erwin, 1990. The relationship between day and night temperature influences photosynthesis but not light compensation point or flower longevity of Easter lily, Lilium longiflorum Thunb. Acta Horticulturae, 272: 91-96.

7. Biermann MR, J Dole, C Rosen and H Wilkins, 1990. Leaf edge burn and axillary shoot growth of vegetative poinsettia plants. Journal of the American Society for Horticultural Science, 115: 73-78.

8. Blakeman J, 1975. Germination of Botrytis cinerea conidia in vitro in relation to nutrient conditions on leaf surfaces. Transactions of the British Mycology Society, 65: 239-247.

9. Chandler S, 2003. Commercialization of genetically modified ornamental plants. Journal of Plant Biotechnology, 5: 69-78.

10. Chandler SF and F Brugliera, 2011. Genetic modification in floriculture. Biotechnology letters, 33: 207-214.

11. Dunn BL, C Goad and S Stanphill, 2011. Performance of 40 poinsettia cultivars grown under two different temperatures. Journal of Horticulture and Forestry, 3: 72-77.

12. Eason JR, 2006. Molecular and genetic aspects of flower senescence. Stewart Postharvest Review, 2: $1-7$.

13. Ecke IP, JE Faust, A Higgins and J Williams, 2004. The Ecke poinsettia manual. Ball Publishing, Illinois, USA.

14. Ecke P, O Matkin and DE Hartley, 1990. The Poinsettia Manual (3 ${ }^{\text {rd }}$ edition). Paul Ecke Poinsettias, Encinitas, California, USA.

15. Ehret DL and LC Ho, 1986. Translocation of calcium in relation to tomato fruit growth. Annals of Botany, 58: 679-688.

16. Faust $\mathrm{J}$ and $\mathrm{A}$ Enfield, 2010. Effect of temperature and storage duration on quality and rooting performance of poinsettia (Euphorbia pulcherrima'Prestige Red') cuttings. Acta Horticulturae, 877: 1799-1807.

17. Faust $\mathrm{J}$ and $\mathrm{K}$ Lewis, 2005. Effect of 1-MCP on the postharvest performance of un-rooted poinsettia cuttings. Acta Horticulturae, 877: 807-812.

18. Faust JE, E Will and R Klein, 1998. Stock Plant environment impacts lateral stem strength of finished poinsettias. HortScience, 33: 448

19. Ferguson I and B Drøbak, 1988. Calcium and the regulation of plant growth and senescence. HortScience, 23: 262-266.

20. Fjeld T, 1990. Effects of temperature and irradiance level on plant quality at marketing stage and the subsequent keeping quality of Christmas begonia (Begonia $x$ cheimantha Everett). Norwegian Journal of Agricultural Sciences, 4: 217-223.

21. Fjeld T, 1992. Effects of temperature and irradiance level on carbohydrate content and keeping quality of Christmas begonia (Begonia cheimantha everett). Scientia Horticulturae, 50: 219-228.

22. Gilbertz DA, JE Barrett and TA Nell, 1982. Effects of water stress on flowering in poinsettia. HortScience, 17: 516.

23. Grange $R$ and $D$ Hand, 1987. A review of the effects of atmospheric humidity on the growth of horticultural crops. Journal Horticultural Science, 62: 125-134.

24. Hammer PA, 1999. Poinsettia problem, diagnostic key: physiological disorders of poinsettias. (http://www.ces.ncsu.edu/depts/hort/poinsettia/corrective/a11.html).

25. Hausbeck $M$ and $G$ Moorman, 1996. Managing Botrytis in greenhouse-grown flower crops. Plant Disease, 80: 1212-1219.

26. Hepler PK, 2005. Calcium: a central regulator of plant growth and development. The Plant Cell Online, 17: 2142-2155.

27. Higaki T, H Rasmussen and W Carpenter, 1980. Color breakdown in anthurium (Anthurium andreanum Lind.) spathes caused by calcium deficiency. Journal of American Society for Horticultural Science, 105: 441-444.

28. Hisamatsu T, RW King, CA Helliwell and M Koshioka, 2005. The involvement of gibberellin 20oxidase genes in phytochrome-regulated petiole elongation of Arabidopsis. Plant Physiology, 138: 1106-1116.

29. Islam MA, D Tarkowská, JL Clarke, D-R Blystad, HR Gislerød, S Torre and JE Olsen, 2014. Impact of end-of-day red and far-red light on plant morphology and hormone physiology of poinsettia. Scientia Horticulturae, 174: 77-86. 
30. Islam MA, G Kuwar, JL Clarke, D-R Blystad, HR Gislerød, JE Olsen and S Torre, 2012. Artificial light provided by light emitting diodes (LEDs) with a high portion of blue light results in more compact poinsettia compared to the traditional high pressure sodium (HPS) lamps. Scientia Horticulturae, 147: 136-143.

31. Islam MA, H Lütken, S Haugslien, D-R Blystad, S Torre, J Rolcik, SK Rasmussen, JE Olsen and JL Clarke, 2013. Overexpression of the AtSHI gene in poinsettia, Euphorbia pulcherrima, results in compact plants PLoS ONE 8, doi:10.1371/journal.pone.0053377.

32. Jiang W, Q Sheng, XJ Zhou, MJ Zhang and XJ Liu, 2002. Regulation of detached coriander leaf senescence by 1-methylcyclopropene and ethylene. Postharvest Biology and Technology, 26: 339345.

33. Jones R, 1999. Poinsettia problem, diagnostic key: Botrytis blight or gray mold. The North Carolina State University, USA. (http://www.ces.ncsu.edu/depts/hort/poinsettia/corrective/c13.html).

34. Kuehny J, P Branch and P Adams, 2000. Stem strength of poinsettia. Acta Horticulturae, 515: 257264.

35. Larson RA, JW Love, DL Strider, RK Jones, JR Baker and KR Horn, 1978. Commercial poinsettia production. North Carolina Agricultural Extension Service. AG-108.

36. Lee YK, P Derbyshire, JP Knox and AK Hvoslef-Eide, 2008. Sequential cell wall transformations in response to the induction of a pedicel abscission event in Euphorbia pulcherrima (poinsettia). The Plant Journal , 54: 993-1003.

37. Love J, 1999. Poinsettia problem-diagnostic key: physiological disorders of poinsettias. North Carolina State University, USA. (http://www.ces.ncsu.edu/depts/hort/poinsettia/corrective/a11.html).

38. Lütken H, JL Clarke and $\mathrm{R}$ Müller, 2012. Genetic engineering and sustainable production of ornamentals: current status and future directions. Plant Cell Reports, 31: 1141-1157.

39. Marschner H, 1995. Mineral nutrition of higher plants. Academic Press, Berlin.

40. McAvoy R and B Bible, 1995. Bract necrosis on poinsettia. Connecticut Greenhouse Newsletter, 188: 17-23.

41. McAvoy R and B Bible, 1996a. Silicate sprays as effective as calcium sprays at suppressing bract necrosis in poinsettia. HortScience, 31: 654

42. McAvoy $R$ and B Bible, 1996b. Silica sprays reduce the incidence and severity of bract necrosis in poinsettia. HortScience, 31: 1146-1149.

43. McAvoy R, B Bible and MR Evans, 1998. Localized accumulation of condensed tannins associated with poinsettia bract necrosis. Journal of the American Society for Horticultural Science, 123: 916920.

44. Michalczuk B, D Goszczynska D, R Rudnicki and A Halevy, 1989. Calcium promotes longevity and bud opening in cut rose flowers. Israel Journal of Botany, 38: 209-215.

45. Miller $S$ and $R$ Heins, 1986. Factors influencing premature cyathia abscission in poinsettia 'Annette Hegg Dark Red'. Journal of American Society for Horticultural Science, 111: 114-121.

46. Moe R, T Fjeld and LM Mortensen, 1992a. Stem elongation and keeping quality in poinsettia (Euphorbia pulcherrima Willd.) as affected by temperature and supplementary lighting. Scientia Horticulturae, 50: 127-136.

47. Moe R, E Fløistad and D-R Blystad, 2006. Impact of light on cyathia abscission and bract discoloration in poinsettia (Euphorbia pulcherrima). Acta Horticulturae, 711: 285-290.

48. Moe R, N Glomsrud, I Bratberg and S Valsø, 1992b. Control of plant height in poinsettia by temperature drop and graphical tracking. Acta Horticulturae, 327: 41-48.

49. Moe R, K Willumsen, I Ihlebekk, A Stupa, N Glomsrud and L Mortensen, 1995. DIF and temperature drop responses in SDP and LDP, a comparison. Acta Horticulturae, 378: 27-33.

50. Mortensen LM, 2000. Effects of air humidity on growth, flowering, keeping quality and water relations of four short-day greenhouse species. Scientia Horticulturae, 86: 299-310.

51. Muller R, M Serek, E Sisler and AS Andersen, 1997. Poststorage quality and rooting ability of Epipremnum pinnatum cuttings after treatment with ethylene action inhibitors. Journal of Horticultural Science, 72: 445-452.

52. Nell $\mathrm{T}$ and $\mathrm{J}$ Barrett, 1985. Nitrate-ammonium nitrogen ratio and fertilizer application method influence bract necrosis and growth of poinsettia. HortScience, 20: 1130-1131.

53. Nell T and J Barrett, 1986a. Growth and incidence of bract necrosis in 'Gutbier V-14 Glory'poinsettia. Journal of American Society for Horticultural Science, 111: 266-269.

54. Nell $\mathrm{T}$ and $\mathrm{J}$ Barrett, 1986b. Influence of simulated shipping on the interior performance of poinsettias. HortScience 21: 310-312.

55. Nielsen B and KR Starkey, 1999. Influence of production factors on postharvest life of potted roses. Postharvest Biology and Technology, 16: 157-167.

56. Odula FO, 2011. Effects of temperature, light and plant growth regulators on fuel-efficient poinsettia production. Clemson University, M.S thesis in Plant and Environmental Sciences. 
57. Prince $T$ and $M$ Cunningham, 1988. Leaf abscission of poinsettias affected by preharvest fertilization termination and sleeving stress. HortScience, 23: 138-139.

58. Pritchard $\mathrm{P}, \mathrm{M}$ Hausbeck and $\mathrm{R}$ Heins, 1996. The influence of diurnal temperatures on the postharvest susceptibility of poinsettia to Botrytis cinerea. Plant Disease, 80: 1011-1014.

59. Ranch PE, 2011. Postproduction issue, commercial floriculture. University of Florida, Environmental Horticulture, Gainesville, USA. (http://hort.ifas.ufl.edu/floriculture/poinsettia/beb.shtml).

60. Ranch PE, 2012. Commercial floriculture. University of Florida. Gainesville, USA. (http://hort.ifas.ufl.edu/floriculture/poinsettia.shtml).

61. Riov $\mathrm{J}$ and $\mathrm{R}$ Goren, 1979. Effect of ethylene on auxin transport and metabolism in midrib sections in relation to leaf abscission of woody plants. Plant Cell Environment, 2: 83-89.

62. Robichaux MB, 2008. The effect of calcium or silicon on potted miniature roses or poinsettias. Master's Thesis, University of Louisiana at Lafayette, USA.

63. Runcle $\mathrm{E}$ and $\mathrm{J}$ Faust, 2008. Energy-efficient poinsettia production. GPN Magazine.( http://www.gpnmag.com/energy-efficient-poinsettia-production).

64. Sacalis J, 1978. Ethylene evolution by petioles of sleeved poinsettia plants [Euphorbia pulcherrima]. HortScience 13: 594-596.

65. Salinas J, DCM Glandorf, F Picavet and K Verhoeff, 1989. Effects of temperature, relative humidity and age of conidia on the incidence of spotting on gerbera flowers caused by Botrytis cinerea. European Journal of Plant athology, 95: 51-64.

66. Saltviet MEJ, DM Pharr and RA Larson, 1979. Mechanical stress induces ethylene production and epinasty inpoinsettia cultivars. Journal of American Society for Horticultural Science, 104: 452-455.

67. Sánchez-Blanco J, T Ferrández, A Navarro, S Bañon and J Alarcón, 2004. Effects of irrigation and air humidity preconditioning on water relations, growth and survival of Rosmarinus officinalis plants during and after transplanting. Journal of Plant Physiology, 161: 1133-1142.

68. Schnelle R and J Barrett, 2011. High temperatures and marginally inductive photoperiods impact the floral display of poinsettias'freedom red', 'early red splendor', and 'prestige early red'. Acta Horticulturae, 893: 873-878.

69. Scott L, T Blessington and J Price, 1983. Postharvest effects of temperature, dark storage duration, and sleeving on quality retention of 'Gutbier V-14 Glory' poinsettia. HortScience, 18: 749-750.

70. Scott LF, TA Blessington and JA Price, 1982. Postharvest performance of poinsettia as affected by micronutrient source, storage, and cultivar. HortScience, 17: 901-902.

71. Scott LF, TA Blessington and JA Price, 1984a. Influence of controlled-release fertilizers, storage duration, and light source on postharvest quality of poinsettia. HortScience, 19: 111-112.

72. Scott LF, TA Blessington and JA Price, 1984b. Postharvest effects of storage method and duration on quality retention of poinsettias. HortScience, 19: 290-291.

73. Serek M, EC Sisler and MS Reid, 1994. Novel gaseous ethylene binding inhibitor prevents ethylene effects in potted flowering plants. Journal of the American Society for Horticultural Science, 119: 1230-1233.

74. Serek M, E Woltering, E Sisler, S Frello, S Sriskandarajah, 2006. Controlling ethylene responses in flowers at the receptor level. Biotechnogy Advances, 24: 368-381.

75. Shanks J, W Noble and W Witte, 1970. Influence of light and temperature upon leaf and bract abscission in poinsettia. Journal of the American Society for Horticultural Science, 95: 446-449.

76. Simpson GG and C Dean, 2002. Arabidopsis, the rosetta stone of flowering time? Science, 296: 285289.

77. Smith T and D Cox, 2009. Lateral stem breakage on poinsettias. University of Massachusetts, USA. (http://www.negreenhouseupdate.info/index.php/september/201-lateral-stem-breakage-onpoinsettias).

78. Staby G, B Eisenberg, J Kelly, M Bridgen and M Cunningham, 1980. Leaf petiole epinasty in poinsettias. HortScience, 15: 635-636.

79. Staby $G$ and A Kofranek, 1979. Production conditions as they affect harvest and postharvest characteristics of poinsettias. Journal of the American Society for Horticultural Science, 104: 88-92.

80. Staby GL, J Thompson and A Kofranek, 1978. Postharvest characteristics of poinsettias as influenced by handling and storage procedures. Journal of the American Society for Horticultural Science, 103: 712-115.

81. Starkey KR and AR Pedersen, 1997. Increased levels of calcium in the nutrient solution improves the postharvest life of potted roses. Journal of the American Society for Horticultural Science, 122: 863868.

82. Strømme E, A Selmer-Olsen, HR Gislerød and R Moe, 1994. Cultivar differences in nutrient absorption and susceptibility to bract necrosis in poinsettia (Euphorbia pulcherrima Willd. ex Klotzsch). Gartenbauwissenschaft 59: 6-12. 
83. Syngenta, 2009. Energy efficient poinsettia production. (http://www.syngentaflowersinc.com/pdf/cultural/FINALPoinsettiaColdGrowing.pdf).

84. Taiz L and E Zeiger, 2010. Plant Physiology (5th edition), chapter: ethylene. Sinauer Assoc. Inc., Publishers, Sunderland, Massachusetts USA. pp: 649-668.

85. Tayma H and T Roll, 1990. Tips on growing poinsettia: (Second edition). The Ohio State University, USA. (http://melissa560.tripod.com/braconbrac1.html).

86. Torre S, T Fjeld and HR Gislerød, 2001. Effects of air humidity and K/Ca ratio in the nutrient supply on growth and postharvest characteristics of cut roses. Scientia Horticulturae, 90: 291-304.

87. Tsutsui $\mathrm{K}$ and M Aoki, 1981. Response of poinsettias to major nutrient supply in relation to nutrient uptake and growth. Bull. Veg. Orn. Crops Res. Station. Series A 8: 171-207.

88. USDA [NASS] 2009. Floriculture crops - 2008 summary. Sp $\mathrm{Cr}$ 6-1. (http://usda.mannlib.cornell.edu/usda/current/FlorCrop/FlorCrop-04-23-2009.pdf).

89. van Doorn WG, 2001. Role of soluble carbohydrates in flower senescence: a survey. Acta Horticulturae, 503: 179-183.

90. Van Meeteren U, 1980. Role of pressure potential in keeping quality of cut gerbera inflorescences, Acta Horticultuare, 113: 143-150.

91. Whipker B, 1999. Poinsettia problems, diagnostic key: physiological disorders of poinsettia. North Carolina State University, USA.

(http://www.ces.ncsu.edu/depts/hort/poinsettia/corrective/a11.html\#a11-01).

92. Whipker BE, C Warfield, R Cloyd, JL Gibson and TJ Cavins, 2002. Avoiding top problems of poinsettias. Green house production news (GPN) in July. North Carolina State University. 24-29. (http://www.gpnmag.com/sites/default/files/Whipker_Warfield.pdf).

93. Woltering E, 1987. Effects of ethylene on ornamental pot plants: a classification. Scientia Horticulturae, 31: 283-294.

94. Woltz S and B Harbaugh, 1985. Effect of nutritional balance on bract and foliar necroses of poinsettia. Proceeding of Florida State Horticulture Society, 98: 122-123.

95. Zhao X, X Yu, E Foo, GM Symons, J Lopez, KT Bendehakkalu, J Xiang, JL Weller, X Liu and JB Reid, 2007. A study of gibberellin homeostasis and cryptochrome-mediated blue light inhibition of hypocotyl elongation. Plant Physiology, 145: 106-118.

96. Zieslin N and A Halevy, 1969. Petal blackening in 'Baccara'roses. Journal of the American Society for Horticultural Science, 94: 629-631. 